\title{
REGIONAL CHARACTERISTICS OF GREENHOUSE GAS EMISSIONS AND DECARBONIZATION OPTIONS IN HUNGARY
}

\author{
Tamás PÁLVÖLGYI ${ }^{a}$, Diana ESSES ${ }^{b}$ \\ a Budapest University of Technology and Economics, Department of Environmental Economics. Address: \\ 1117 Budapest, Magyar tudósok körútja 2., Q building (A wing) e-mail: palvol@eik.bme.hu \\ ${ }^{\mathrm{b}}$ Budapest University of Technology and Economics, Department of Environmental Economics. Address: \\ 1117 Budapest, Magyar tudósok körútja 2., Q building (A wing) e-mail: esses.diana@eik.bme.hu
}

Cite this article: Pálvölgyi, T., Esses, D. (2019). Regional Characteristics of Greenhouse Gas Emissions and Decarbonization Options in Hungary. Deturope. 11(3), 93-109.

\begin{abstract}
On the basis of common and unified methodologies, NUTS3 (county) level climate change strategies have been completed in Hungary. The strategies also consist comprehensive inventories of greenhouse gas (GHG) emissions, as well as quantified decarbonization (emission reduction) targets for the years of 2020, 2030 and optionally, 2050. The primary objective of the paper is to identify the spatial structure of the GHG emissions and to assess the interconnection between NUT3 level economic development and emission patterns. Comparative analyses of the county's decarbonization targets are also presented in order to assess their contribution in the national commitments under Paris Agreement. Results suggest that NUTS3 level $\mathrm{CO} 2$ emissions show a typical spatial pattern with a strong interrelation with county's socio-economic typology. Finally, the paper provides suggestions to integrate the regional characteristics of decarbonization into county's transition to sustainable development.
\end{abstract}

Keywords: climate change strategy, decarbonization target, regional sustainable development, Hungary

\section{INTRODUCTION AND LITERATURE OVERVIEW}

It is a recognized fact that climate change is a global phenomenon which affects different societies as a whole: individual settlements and entire regions. In order to respond effectively to climate change, global players at different levels require both methodology and tools for decision making process. Mitigation and adaptation might be complementary at some levels, but they can be contradictory at some point. Therefore, the development of a methodology and a tool to help individuals, communities, countries or regions in the decision-making process towards the best response to climate change is required. (Laukkonen et al, 2009)

The current integrated energy and climate policy has proposed a $20 \%$ reduction in GHG (greenhouse gases) in the Member States by 2020. One of the principal tools is to improve energy efficiency under the energy efficiency action plan, which is supposed to cut the entire energy usage by $20 \%$ by 2020 . On the other hand, the amount of energy from renewable sources 
consumed in Europe will have to rise to $20 \%$ by 2020. These are ambitious but achievable aims. (Carvalho, 2012)

Countries are implementing $\mathrm{CO} 2$ emission reduction targets in order to meet a globally agreed global warming limit of $+1,5^{\circ} \mathrm{C}$. Strategic Environmental Assessment is a particularly suitable tool for the study of climate protection at regional level. This tool makes it possible to assess the effects of environmental parameters listed in the legislation, such as soil, biodiversity, water, etc. It is necessary to have global climate change protection targets on regional and local levels as well. Territorial and urban planning, in particular, has a huge potential for reducing energy and $\mathrm{CO} 2$ emissions, as well as other greenhouse gases. This issue must properly be addressed in the planning and decision making processes at the level of municipalities. (Wende et al, 2012).

The Competitive Cities and Climate Change Study is based on the results of existing research and recent developments in OECD countries. It is focused on two issues: the local and multilevel dimensions of urban climate management. Many cities are not yet making use of the opportunities to implement climate protection measures through "hard" regulation and strategic planning. (OECD, 2008)

The emissions of carbon-dioxide and other greenhouse gases are one of the most important indicator on transition to sustainable development (Iyer et al, 2018). The calculation of total greenhouse gas emissions in Hungary is estimated to 63,8 million tonnes in 2017 (HMS, 2019) which has shown a slight increasing tendency for last 5 years. A few Hungarian cities have also prepared and adopted Sustainable Energy-Climate Action Plans (SECAP). In accordance with the Guidelines of Covenant of Mayors (Bertoldi, 2018), the baseline greenhouse gas emission inventories (i.e. calculations of emissions) should be a compulsory and central element of the SECAP documents, therefore, in case of 35 cities, estimation on the city-level greenhouse gas emissions are available. In spite of existing CO2 emission figures on national and (in some cases) city level emissions, the spatial structure of greenhouse gas emissions is still unknown in Hungary. The primary goal of our research is to identify and analyze the NUTS-3 level distribution of greenhouse gas emissions in Hungary, as well as to determine the possible interrelations between the county's greenhouse gas emissions and their socio-economic circumstances.

It is also a relevant science-based and policy-relevant question that how can the local and regional level municipalities (for example cities, counties) contribute in national level greenhouse gas emission reduction commitments. National Climate Change Strategy (NCCS- 
2, 2018) adopted by the Parliament in 2018 clearly stated that national greenhouse gas emissions should be reduced at least by $40 \%$ until 2030 (compared to 1990 level). It means further 13\% decrease in GHG emissions related to 2017 figures. Nevertheless, no information has revealed on the possible regional effort sharing until now therefore another goal of the present paper is to present a comparative analysis of the decarbonization targets (i.e. NUTS-3 level emission reduction targets for 2030) of Hungary's counties. Finally, the county's climate change related policy responses should also be an important information on regional sustainable development. In order to determine the spatial characteristics of these policy responses a classification of climate change mitigation measures planned by the county's municipalities is also shown.

\section{METHODOLOGICAL BACKGROUND}

Methodological framework of our research is based on the general socio-economic conditions in NUTS-3 level in Hungary. Regional differences can be observed in every country and are constantly changing, due to geographical conditions, environment, political situation and other influencing factors. The smaller the territorial level wherein the differentiation is examined, the more differences can be detected. (TOP, 2014). The most commonly used indicator for the spatial comparison of economic development is the gross domestic product per capita. The most important factors influencing the economic development are the spread of enterprises, investments, highlighting housing investments, foreign investments in the capital supply, and R\&D activities. (CSO, 2013)

A country's GDP is made up of the GDP of its regions. In accordance with the principle of subsidiarity, the counties in Hungary are suitable for the study of regional differences and thus properly small units to reduce regional disparities. As it is presented in Tab. 1, Hungary is highly differentiated, with the standard deviation of the county's per capita GDP being the second largest in the EU. (TOP, 2014). In terms of GDP per capita of 19 counties and Budapest, the capital's outstanding value and the development of three Transdanubian counties (GyörMoson-Sopron, Fejér and Komárom-Esztergom) are conspicuous. Of the 19 counties, the county of Nógrád is the farthest from the national average. 
Table 1 Tendencies in economic performance of Hungarian counties: GDP/capita (millions Ft/capita)

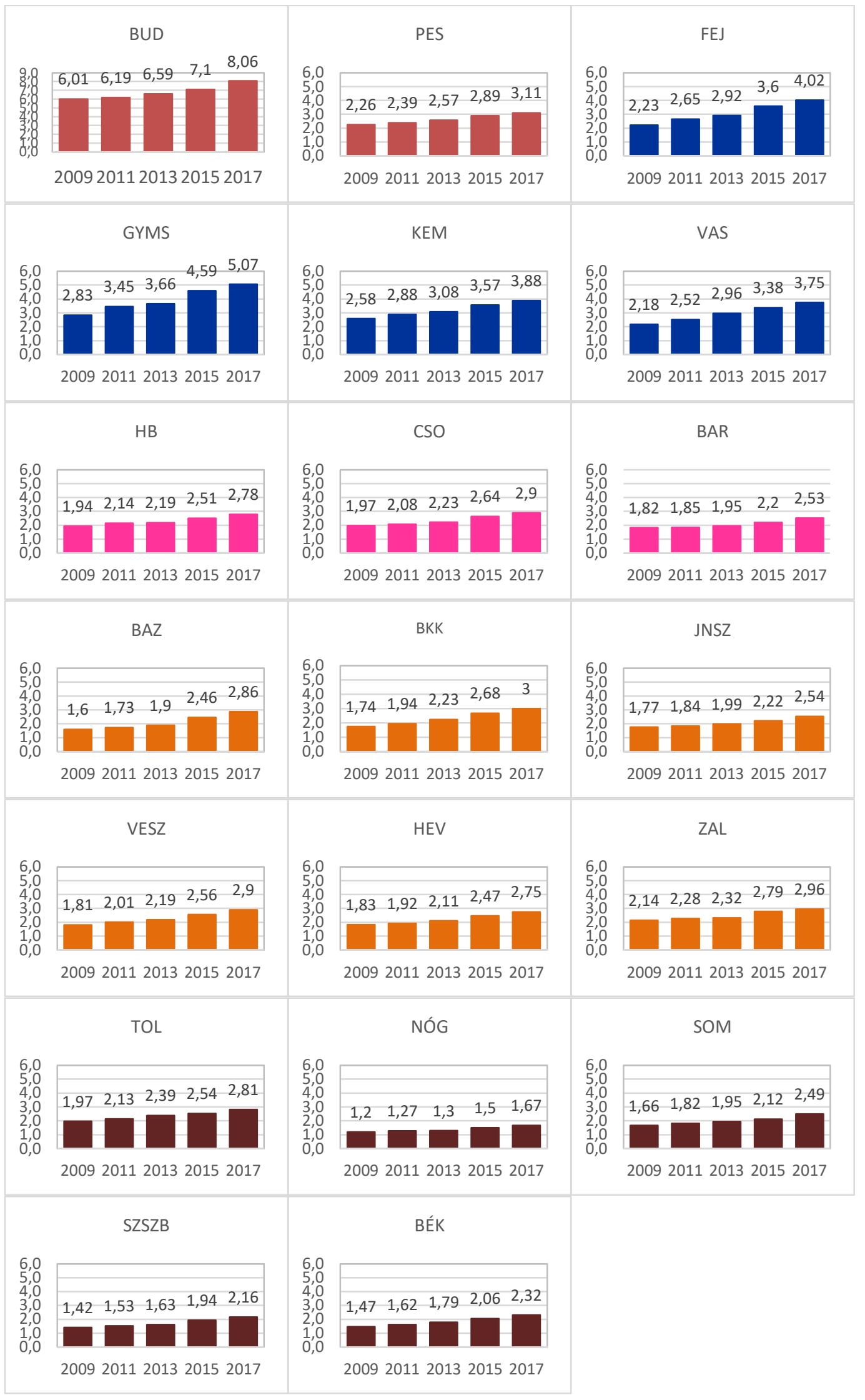

Source: CSO, 2018 (own editing) 
According to a classification of counties based on their similar socio-economic conditions and developmental paths (Lengyel and Varga, 2018), 86\% of the population of Central-Hungary live in Budapest and its districts, which is why Budapest and Pest County became center counties (Tab. 2). The other types of counties were classified based on their economic growth observed from 2000 to 2012, the 2016 GDP-value and their economic structure. The spatial location of the county types is crucial; industrial counties where foreign direct investment flows into are located in Northern Transdanubian, in its neighborhood or near Budapest. Reindustrializing counties can be found in traditionally industrial areas (such as Borsod-AbaújZemplén). The rural counties are located at the southern eastern border. Nógrád County is slightly out of this scheme, although it is located at the border, as 14 out of 19 counties, but despite its geographical proximity to Budapest, its economic performance is very weak. Based on the annual growth rates of the Hungarian economy, one can distinguish three periods: the periods 2000-2006, 2007-2012 and 2013-2016. In the period of 2000-2006, the economy increased in varying degrees, but everywhere. Downturn and stagnation can be observed between 2007 and 2012, but from 2013 economy began to rise and expand in every county again.

Table 2 Socio-economic typology of counties in Hungary

\begin{tabular}{|l|l|l|}
\hline County Types & County's name & $\begin{array}{l}\text { Abre- } \\
\text { vation }\end{array}$ \\
\hline Central & Budapest & BUD \\
\cline { 2 - 3 } & Pest & PES \\
\hline Industrial & Györ-Moson-Sopron & GYMS \\
\cline { 2 - 3 } & Fejér & FEJ \\
\cline { 2 - 3 } & Komárom-Esztergom & KEM \\
\cline { 2 - 3 } & Vas & VAS \\
\hline \multirow{5}{*}{ Re-industrializing } & Bács-Kiskun & BKK \\
\cline { 2 - 3 } & Zala & ZAL \\
\cline { 2 - 3 } & Veszprém & VESZ \\
\cline { 2 - 3 } & Heves & HEV \\
\cline { 2 - 3 } & Borsod-Abaúj-Zemplén & BAZ \\
\cline { 2 - 3 } & Jász-Nagykun-Szolnok & JNSZ \\
\hline Knowledge Center & Baranya & BAR \\
\cline { 2 - 3 } & Csongrád & CSO \\
\cline { 2 - 3 } & Hajdú-Bihar & HB \\
\hline Rural & Tolna & SOL \\
\cline { 2 - 3 } & Somogy \\
\cline { 2 - 3 } & Békés & SZSZB \\
\cline { 2 - 3 } & Szabolcs-Szatmár-Bereg \\
\cline { 2 - 3 } & Nógrád & NÓG \\
\hline
\end{tabular}

Source: Lengyel and Varga (2018)

It can be stated that there are significant differences between the counties in Hungary, and that regions with different levels of development cannot be managed with the same economic 
development action plan. (Lukovics, 2012) In order to increase the long term and sustainable competitiveness of the counties, mapping the strengths and weaknesses of the counties is inevitable (Bajmócy, Gébert, and Málovics, 2017).

Second pillar of our research's theoretical framework is the methodology for preparation of NUTS3-level climate change strategies. The climate change strategies (both international, national, territorial, sectoral or company levels) may provide a unique framework for decision making related to climate change policy integration in fields of GHG emission reduction (mitigation) and improvement the climate resilience (adaptation) as well. According to the most recent assessment of Intergovernmental Panel on Climate Change (IPCC), unless global greenhouse gas (GHG) emissions are reduced by 45 percent by 2030 related 2010 levels, a 1.5 $\mathrm{C}$ global warming and serious climate change impacts in local levels are expected until 2030 (IPCC, 2018). Although, under the Paris Climate Agreement nations should complete their national climate plans by 2020 , it is also widely acknowledged that the current national strategies and plans are insufficient to limit global warming to 1,5 C. The Paris Agreement also recognizes that local and regional municipalities play a critical role in global climate action. Achieving more ambitious emission reduction objectives as well as improve the preparedness for adverse local and regional effects of climate change a clear and reinforced role of multilevel governing cooperation is required. This multilevel governing needs harmonized and coordinated preparation of climate change related strategic documents (i.e. climate change strategies, action plans) at different levels of municipalities. It also means that a unified framework for climate change policy planning in rural settlements, cities micro-regions and counties should also be developed.

Environmental and Energy Efficiency Operative Programme of Hungary funded by EU Cohesion Fund and Regional Development Fund support sustainable growth and contribute to achieving the Europe 2020 targets for smart, sustainable and inclusive growth (EEE OP, 2015). The EEE OP has thematic priorities on transition to low-carbon economy, as well as climate change risk prevention and a special target on preparation of municipal-level climate change strategies. A compulsory output indicator has also been set to this special target: the cumulate number of inhabitants in settlements which adopted climate change strategies should reach at least 3 million inhabitants until 2023. In order to fulfil this requirement a three pillars grant scheme has been established:

- 1st pillar: capacity building to develop methodological framework of strategy making at different level of municipalities, promote knowledge transfer and provide professional assistance for municipalities. 
- $2^{\text {nd }}$ pillar: support the NUTS-3 level climate change strategy making. (Beneficiaries: county's municipalities)

- $3^{\text {rd }}$ pillar: support the settlement level (villages, towns, cities) climate change strategy making. (Beneficiaries: settlement's municipalities)

In the framework of methodological development, the Alliance of Climate-Friendly Municipalities (as a beneficiary of 1st pillar's grant), in cooperation with National Adaptation Center of Geological and Geophysical Institute of Hungary was responsible to develop five separate guidelines for climate change strategy of (1) counties, (2) the capital (Budapest) (3) cities, (4) small towns, villages and (5) multi-settlements (Bíró et al, 2017).

According to the methodology of county's climate change strategies, these documents should consist the following major elements:

- Inventories of greenhouse gas emission and removals

- Past and present experiences in sustainable energy and transport related projects, as well as adaptation and climate change risk related projects

- Climate change related SWOT analysis and problem tree

- Elements of county's climate change policy: decarbonization target setting and objectives of improvement of resilience

- Climate change actions: mitigation, adaptation and awareness related measures

- Implementation framework: institutional settings, progress indicators, monitoring processes During 2017-2018, all 19 counties and Budapest have prepared their first climate change strategy. The strategies have been developed under the assistance and supervision of Alliance of Climate-Friendly Municipalities and approved by the Assemblies of County's Municipalities. According to the efficient multilevel governance, these documents are fully consistent by the Hungary's Second National Climate Change Strategy (NCCS-2, 2018) adopted by the Parliament October 2018.

The adopted county's climate change strategies form the main analytical background of present paper. The data of county's inventories of greenhouse gas emission and removals are used to identify spatial distribution of $\mathrm{CO} 2$ emissions. An important conclusion of the quality check of county's inventories of greenhouse gas emission and removals were to find significant inconsistencies in estimation of $\mathrm{CO} 2$ emissions from ETS sectors. (ETS sector covers the power plants, cement factories, steel production and other hard industry facilities. These installations are obligatory take part in EU emission trading system.) Therefore, the county's estimation of $\mathrm{CO} 2$ emissions does not include the industrial sources from ETS sectors. 
The county's CO2 quantified emission reduction targets for 2030, as well as the planned main mitigation actions are also derived from the county's climate change strategies. During the strategy's preparation, an independent review and quality control was made by the Alliance of Climate-Friendly Municipalities ("methodology developer"), therefore the data used for spatial analyses may consider as best available source of relevant information.

\section{RESULTS AND DISCUSSION}

As it is mentioned above, the aim of climate change strategies is to provide the conditions for mitigation and adaptation activities using a uniform and common climate strategy methodology. The first stage of county climate strategies is the assessment of the situation. Although, the focal part of the present research is mitigation, while the assessment of the situation of the counties, the evaluation of climate and energy awareness as well as the SWOT analysis and the problem map of the climatic aspects have also been prepared in the county's climate change strategies. In the course of the mitigation, the inventory of the county's greenhouse gases (GHG) was compiled. The preparation of GHG inventories was assisted by the Alliance of Climate-Friendly Municipalities giving software support and professional guidance (ACFM, 2018). With the help of the SWOT analysis, the counties were able to assess their strengths and opportunities more easily, they learned about their weaknesses and external threats, which can be used to map the mitigation and adaptation possibilities of the counties. After the assessment of the situation, the strategic connection points were determined, examining the connection points of the county level and their relationship with the regional and local documents. In this part the counties also introduced sustainable energy management projects that had already been implemented. With this in mind, the county's climate protection vision was elaborated. At the end of the strategic documents, the arrangement of implementation is shown, which included the planning of the county level measures and the identification of the implementation framework. The quantification of the county's decarbonization targets - expressed as the county's GHG emission reduction target (\%) - is not mandatory for the counties, and the methodology only makes a recommendation. In present paper we examined mainly the county's GHG emission figures and the decarbonization targets, thereby making regional differences more visible.

First of all, we studied the GHG emissions of counties. (It is important to note that $\mathrm{CO} 2$ emissions shown in Fig. 1 do not include the heavy industry.) In the case of the first three counties (Budapest, Pest and Borsod-Abaúj-Zemplén) the high emissions are attributed to the larger population and the outdated building stock. 
Figure 1 Annual $\mathrm{CO}_{2}$ emissions of counties in 2015

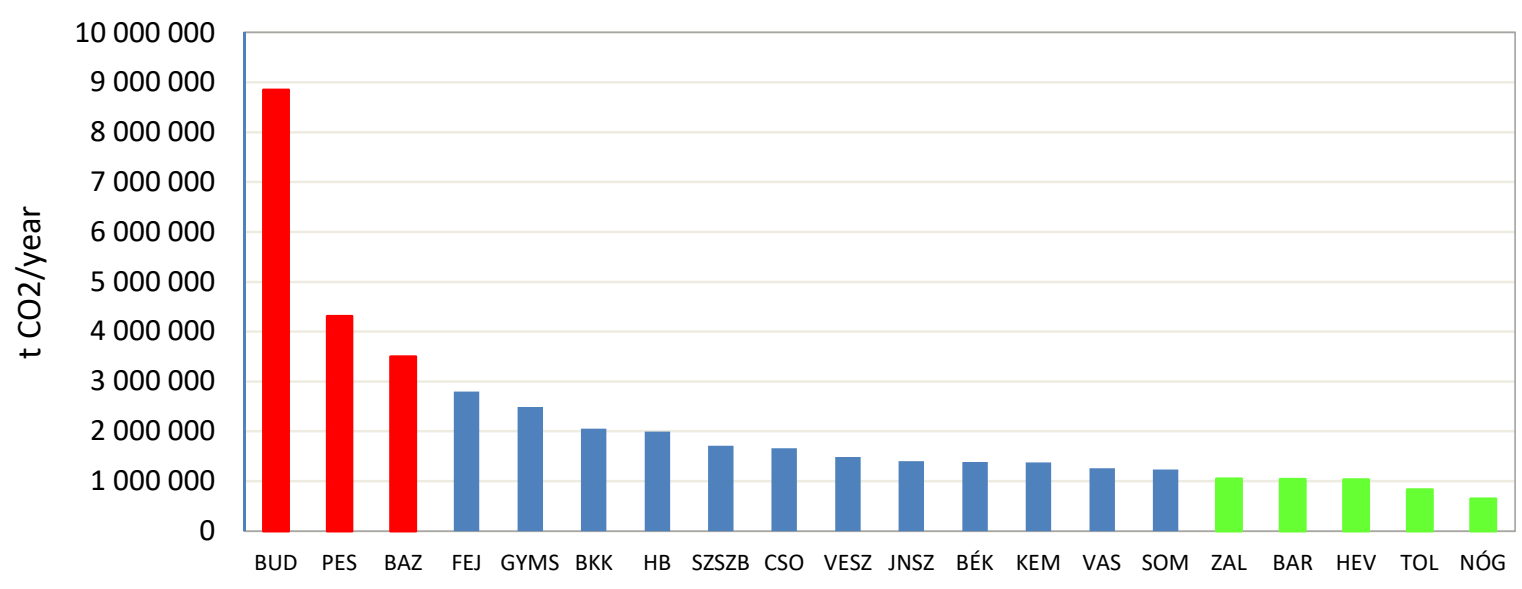

Source: own work

Looking at the last county, the building stock is not more advanced, but the population is smaller and the productive sectors (such as services, industry) is rather weak in Zala, Baranya, Heves, Tolna and Nógrád counties. As it is shown by Zhou, Liu, Wu, and Li (2015) the urbanization processes in Pest, Győr-Moson-Sopron and Fejér counties are also form driving factors of relatively high emissions.

Examining the specific carbon dioxide emissions of the counties (Fig. 2), we concluded that most of the counties were below the national average.

Figure 2 Specific $\mathrm{CO} 2$ emissions of counties

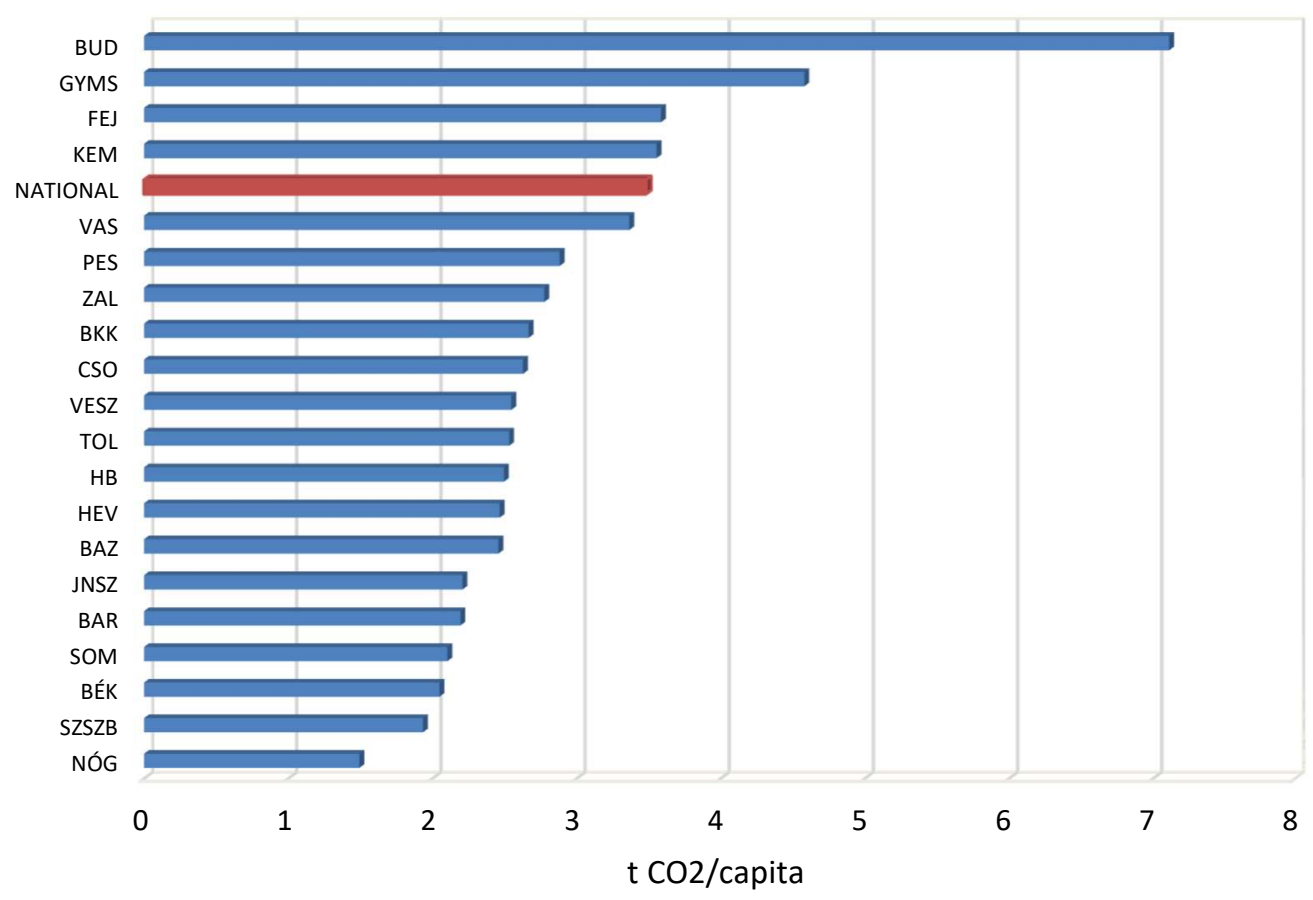

Source: own work 
The chart includes emissions from the SME sector, but not from the heavy industry. This is because ETS (emissions trading system) mandatory quota trading applies to large-scale companies. In these companies, there is no intention to reduce $\mathrm{CO} 2$ emissions, as the quota set by the European Union is mandatory for them, which the EU has reduced year by year. As a result, companies that produce less $\mathrm{CO} 2$ can sell excess quotas on a market basis to larger emission companies. In Hungary, approximately 250 facilities are in the ETS. According to the chart, mobility as a key factor must be highlighted, as transport significantly raises specific emissions, mainly in the counties of Fejér, Győr-Moson-Sopron and Borsod-Abaúj-Zemplén.

We also examined the carbon intensities of county's GHG emissions. (Fig.3).

Figure 3 Carbon intensity ( $\mathrm{CO} 2 / \mathrm{GDP})$ of the counties

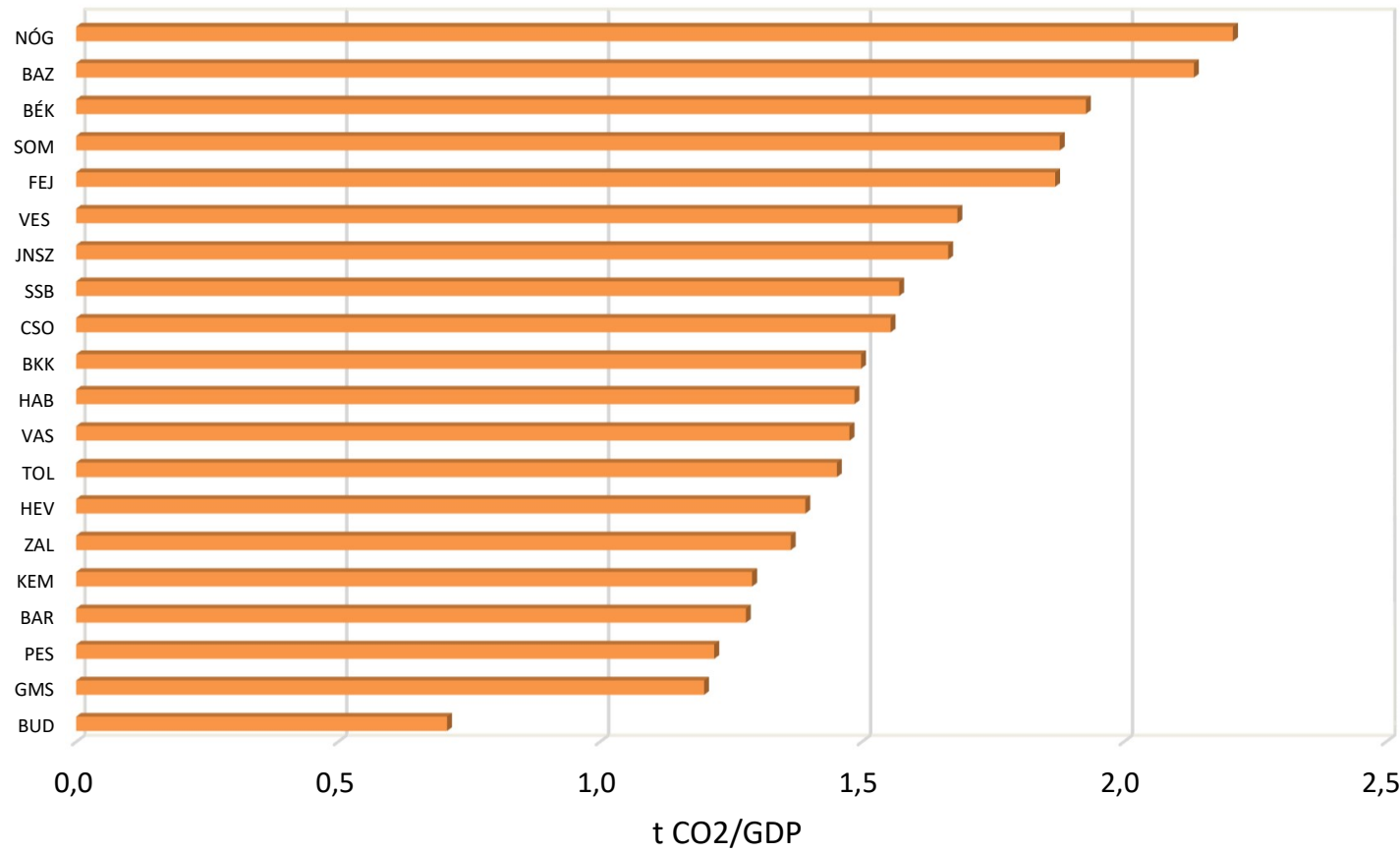

Source: own work

In counties with relatively low county GDP, this index is high, such as the counties of Békés and Somogy. Where the county GDP is high (Budapest, Györ-Moson-Sopron, Pest counties) this index is lower. In the case of Fejér and Veszprém counties the GDP is not low, but it is rather average, but their output is very high. Although the carbon intensity indicator is widely used, but its driving factor is mainly based on GDP so more economic effects are accumulated in the results. 
We also identified the relationship between county development typology and specific emissions. As it is shown in Tab. 2, the counties were clustered into 5 types: central, industrial, re-industrializing, knowledge-center and rural.

Figure 4 Relationship between the economic development (GDP / capita) and specific CO2 emissions ( $\mathrm{t}$ [CO2] / capita) of mixed types

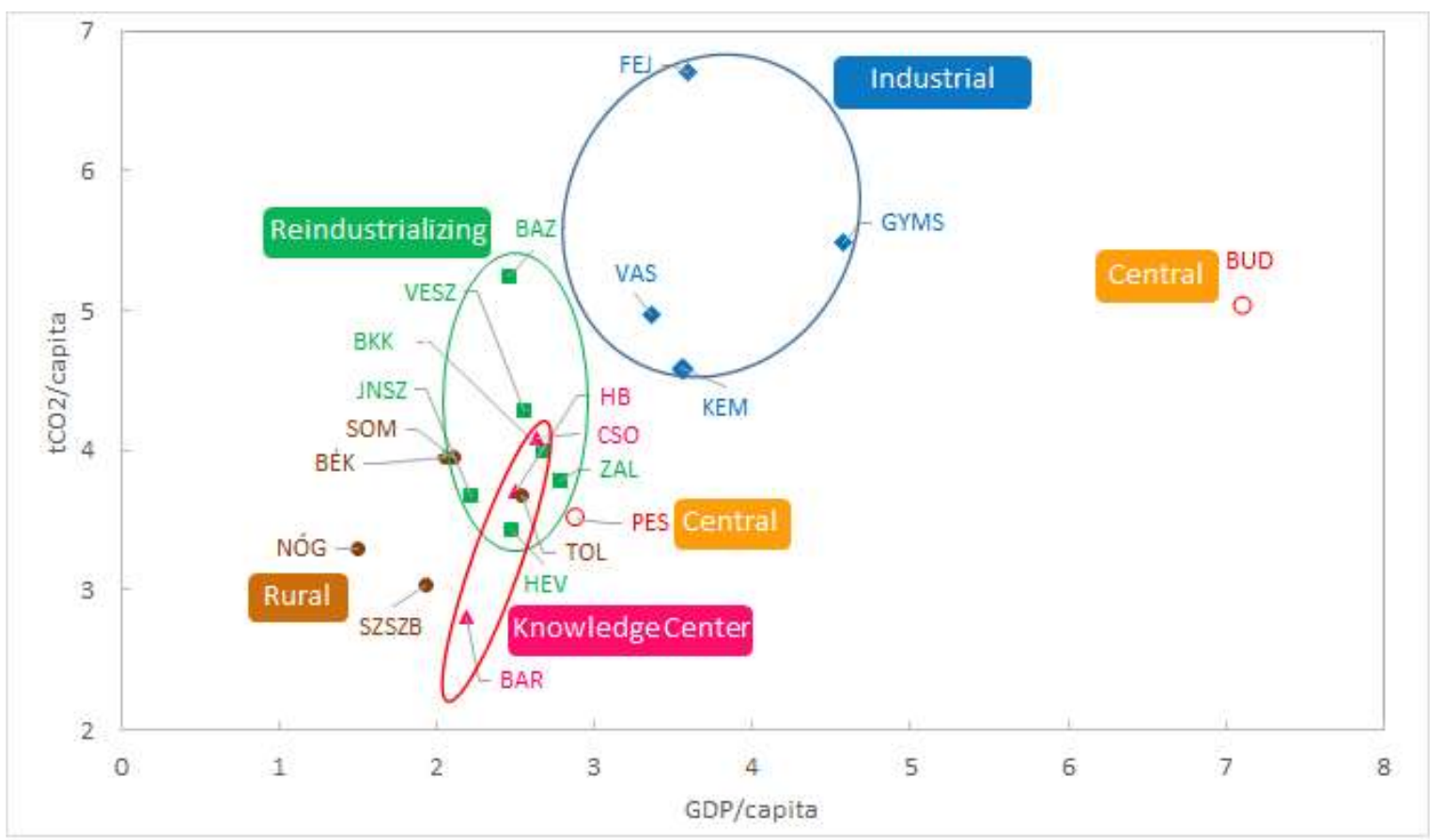

Source: own work

Strong relationships among the county's socio-economic conditions and county's $\mathrm{CO} 2$ emissions are revealed. One of the key factor of this relation is the composition and status of NUTS-3 level household's building stock. Almost 30\% of the total CO2 emissions are attributed to household's heating. The heating demands depend on the status of thermal insulations and In certain rural regions in Hungary the energy poverty is the main factor of household's energy consumption. A widespread practice to minimize the energy costs that certain rooms are not heated and the "remaining" heating is provided by fuel wood or illegal fuels (such as waste and plastics.) (Ürge-Vorsatz \& Herrero, 2012). This environmentally harmful and health risky heating practice may cause a "virtual" energy saving (i.e. less energy consumption in the energy statistics) and less heating-related $\mathrm{CO} 2$ emissions. Therefore, the less developed rural county's (such as Nógrád, Baranya, Szabolcs-Szatmár-Bereg Counties) can be attributed by the lowest per capita emissions.

Another important factor of county's emissions and socio-economic conditions is the role of transport demands and welfare effects. The second major source of $\mathrm{CO} 2$ emissions is the road 
transport, the growth rate exceeds 5\% per year since 2014, in Hungary. Those counties which have significant development in processing industry and service sector (such as automotive assembling or commercial activities) their freight transport-related $\mathrm{CO} 2$ emissions are also increased. In parallel with their relatively developed economic status, social welfare indicators also show prosperous performances in certain Trans-Danubian Counties (such as Budapest, Győr-Sopron-Moson, Fejér Counties). In case of these developed counties, CO2 emissions related to transportation of goods, household's energy consumption and use of cars are also more intensive which cause highest per capita emissions.

It is also noticeable that the most favourable area would be high GDP low emissions, with the closest areas to the center, highlighting Budapest. The counties belonging to the manufacturing industry are characterized by high GDP, but this is accompanied by too high emissions, which is not sustainable. The knowledge center and re-cultivating and rural-type counties emit less, but their GDP is relatively low. They should move horizontally in the development of the chart, taking sustainability into account, i.e. to increase GDP so that their specific emissions do not increase.

Finally, we made a comparative assessment of county's decarbonization targets. Overall, county commitments can be found between 5-20\% compared to base years. In 13 counties, commitments with a rather low level of ambition have been made; reduction commitments were lower than $15 \%$.

Figure 5 County decarbonization targets (quantified emission reduction commitments) for 2030

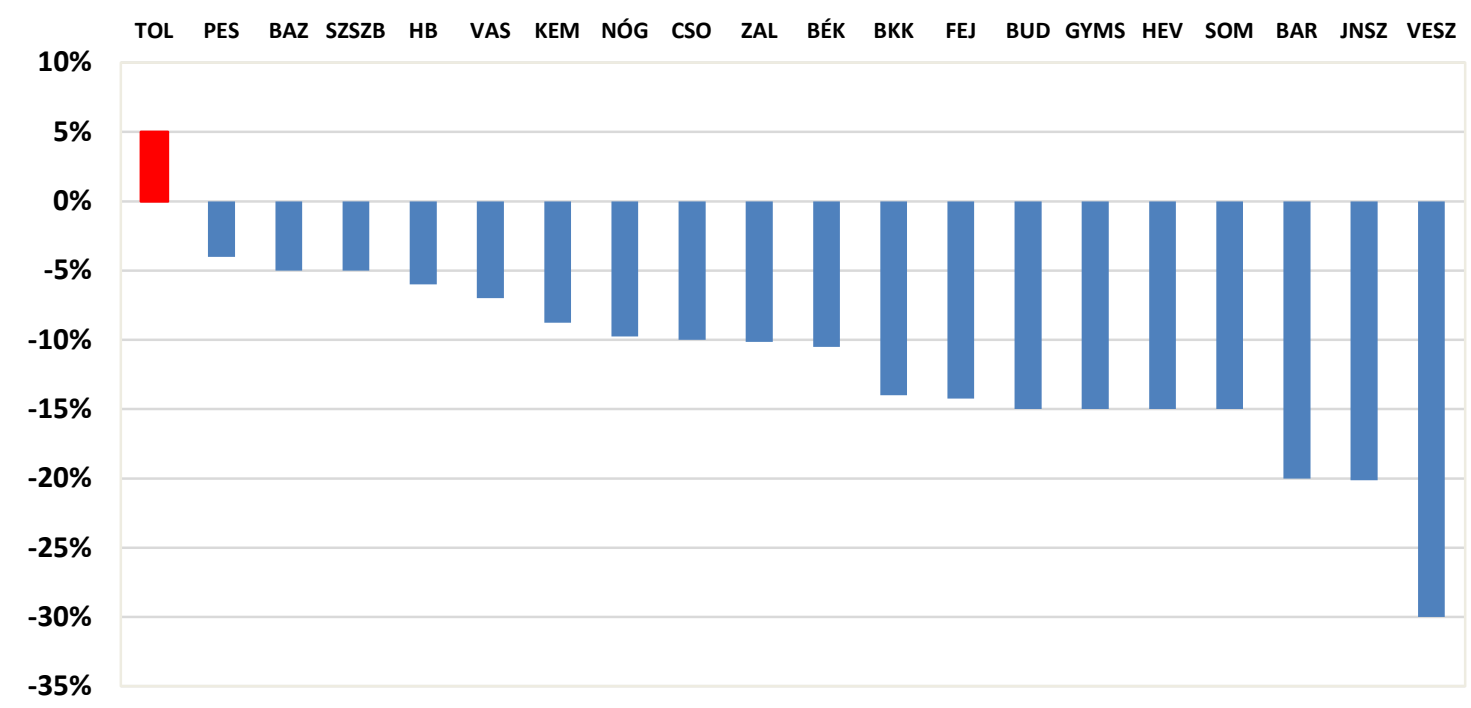

Source: own work

It has been revealed that county's commitments do not adequately reflect their economic development. It also means that there is a lack of consistency between present emission and its 
GDP-related position. This is due to the fact that quantified emission reduction commitments are not yet well established, there is no appropriate policy or development-related justification for county commitments. Fig. 5. shows clearly that different counties have differentiated commitments by 2030 . In the case of commitments by 2020 , it does not reach $6 \%$ in 18 counties. By 2050, the counties did not make very ambitious commitments, and 6 counties did not undertake, while others committed a $10-40 \%$ reduction in $\mathrm{CO} 2$ emissions to the base year.

Figure 6: $\mathrm{CO}_{2}$ emission projections, county and city commitments by 2030

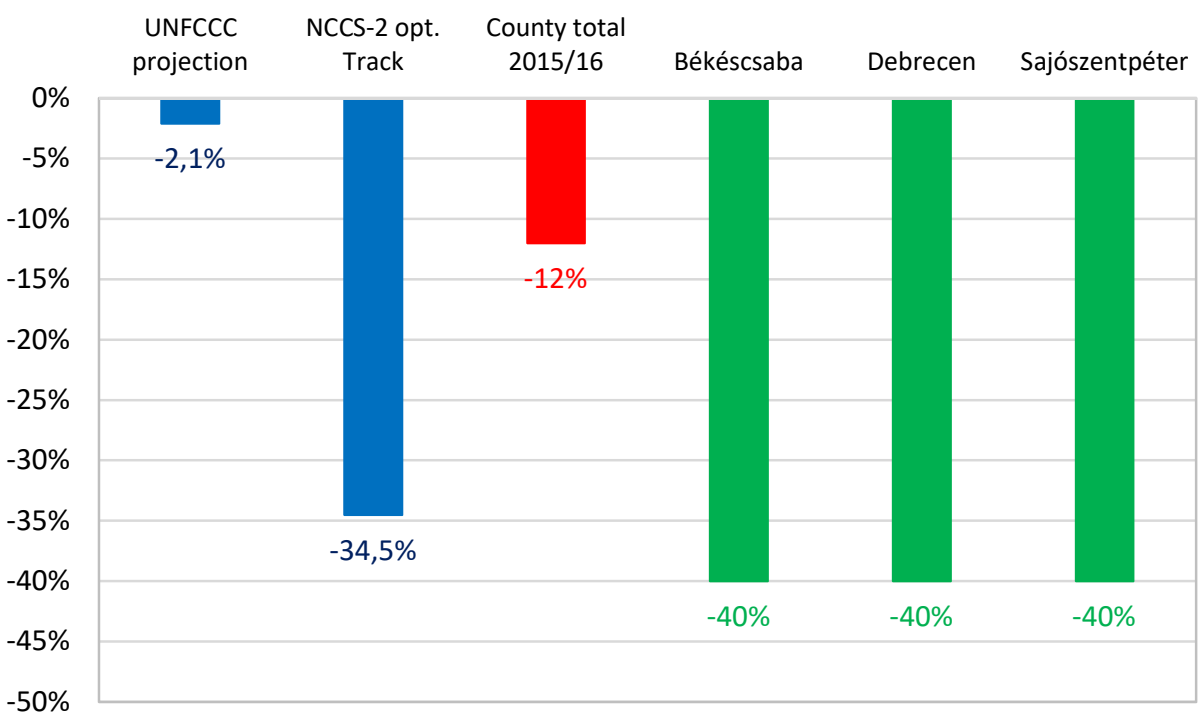

Source: own work

Fig. 6. illustrates that there are more serious ambitions for emission reductions in SECAP documents approved by municipalities. Emissions are concentrated in cities, so it is very encouraging that they are dealing with this problem. The second National Climate Change Strategy (NÉS2) contains $34.5 \%$ national commitment of reduction. In fact, this is the path for optimal emission reduction. All countries must submit reports to the UNFCCC (Framework Convention on Climate Change), based on the most recently submitted document, a $2.1 \%$ Hungarian commitment, but it is important to point out that this is a "wors case" projection. It can be seen that the counties are in an intermediate state with regard to the objectives.

\section{CONCLUSION}

On the basis of climate change strategies recently adopted by county's municipalities, the regional structure of NUTS-3 level greenhouse gas emissions as well as county's mid-term decarbonization targets and mitigation actions have been analyzed. The results may be regarded as a first attempt to specify the spatial characters of the greenhouse gas emissions and related 
policy options in Hungary. We summarize the major consequences in the following four conlusions.

1. Target settings for decarbonization. One of the most important policy-related elements of county's climate change strategies are the quantified emission reduction objectives for 2030 . Decarbonization measures may also contribute in regional economic development and improvement of competitiveness (Zsibók \& Sebestyén, 2017). The decarbonization target value is a comparable, easy-to-communicate indicator which should directly contribute in national level greenhouse gas emission reduction commitments. It has also been revealed that county's contribution to national commitments outlined in Second National Climate Change strategy are generally insufficient. Some cities and towns have stronger ambitions in emission reduction stated in their SECAP documents which highlights the importance of climate change policy coordination between the counties and their cities. We have found that no characteristic spatial distribution is shown in county's pledges. Although, the set of decarbonization target should be based on estimation of mitigation costs, as well as consideration of financing potential of the major stakeholders (i.e. households, public utilities, municipalities) the approved decarbonization target values do not reflect the county's economic and fiscal positions. During the decision making process related to target settings the municipalities paid less attention to the objective cost figures and the dominant decision-driving factor probable based on political prudentialism (i.e. "lower target brings less problems"). Certain guidance rules on recommended county's pledges from the national climate policy makers were also missing. Enabling policy framework for financing and implementing mitigation actions are also important. County's climate change strategies envisaged a broad array of various mitigation measures providing innovative, cost effective way to reduce the greenhouse gas emissions. Majority of counties planned certain "common and preferred" mitigation actions, such as awareness rising and education, grant scheme for housing and public sector's investments in renewables and energy efficiency improvements. Further researches are needed to identify the general typology of mitigation measures and to develop a comprehensive municipal-level climate change policy performance index. Dissemination of best examples and experiences gained should also be a possible extension of the strategy making.

2. Development of methodology for county's climate change strategy making. As it is mentioned above, preparation of county's climate change strategies was guided by a common methodology, certain weakness and room for improvements have been identified during the quality control (Pálvölgyi and Czira, 2018). An important gap is the lack of estimation on 
emission reduction of the planned mitigation measures. Without bottom-up indicators of mitigation performance at level of individual measures, their contribution in county's quantified reduction target is generally unknown. Assessing the transport related emissions should also be improved, especially in case of estimation of transit freight trafic. Forests provide significant ecosystem services in national and regional level and reforestation is an important indicator of sustainable land use at county-level as well. Presently, the estimation of carbon removal is limited in methodological scope and enhance of sink capacites by afforestation measures are almost missing. There are many other minor gaps and challenges of methodological improvement which should be solved during the revision of strategy making guidelines under the implementation of Second National Climate Change Strategy in next few years.

3. Implication for regional sustainable development. One of the most important challenge ahead our regional decision making is to provide an adequate policy framework for transition to sustainable development. According to National Framework Strategy for Sustainable Development (NFSSD, 2013), renewed municipality level planning tools are necessary to achieve sustainable development goals, including poverty alleviation and mitigation of climate change. The county's municipalities have a unique role to play in creating opportunities to integrate decarbonization targets into settlement's development strategies and promoting the territorial cohesion (Lennert, Csatári, Farkas \& Mezőszentgyörgyi, 2015). For example, the county level $\mathrm{CO} 2$ reduction target setting or recommended mitigation measures may form important guiding dimensions for settlement level "Smart City" concepts and SECAPs. While this paper focuses on regional characteristics of climate change mitigation, the general approach may be applied to other regional level policies, including energy efficiency improvement and utilization of renewable energy sources. Territorial impact assessment (TIA) may be regarded as an effective tool of the policy integration of county's decarbonization policies into their settlement's strategy planning (Camagni, 2017). Although, county's municipalities have no direct "command-and-control" function in settlement's governance, their new roles (Hoffman, 2018) may also promote transition to sustainable development by guiding the settlement's climate change policies. Finally, the importance of forests in county's climate change policies should be highlighted. Forests currently absorb billions of tons of $\mathrm{CO} 2$ globally every year. Consequently, the forests contribute to climate change protection through this process. Largescale conversion of forestry and, in particular, afforestation and land use can lead to unwanted environmental and socio-economic impacts that could jeopardize the overall value of carbon reduction projects. (Canadell \& Raupach, 2008) 


\section{Acknowledgement}

The research reported in this paper was supported by the Higher Education Excellence Program of the Ministry of Human Capacities in the frame of the Water sciences \& Disaster Prevention research area of the Budapest University of Technology and Economics.

\section{SUPPORTED BY THE ÚNKP-18-3 NEW NATIONAL EXCELLENCE PROGRAM OF} THE MINISTRY OF HUMAN CAPACITIES

\section{REFERENCES}

ACFM (2018). Knowledge and database of county-level climate change strategies (in Hungarian). Association of Climate-Friendly Municipalities, http://klimabarat.sreter.eu/ Dowload 2018. November

Bajmócy, Z., Gébert, J., \& Málovics, G. (2017). How to evaluate local economic development projects from a people-centred perspective? An analytical framework based on the capability approach. Deturope, 9, 2, 4-24.

Bertoldi P. (editor) (2018). Guidebook 'How to develop a Sustainable Energy and Climate Action Plan (SECAP) - Part 1 - The SECAP process, step-by-step towards low carbon and climate resilient cities by 2030, EUR 29412 EN, Publications Office of the European Union, Luxembourg, 2018, ISBN 978-92-79-96847-1, doi:10.2760/223399, JRC112986

Bíró, M., Kajner, P., Pálvölgyi, T., Rideg, A., Selmeczi, P., \& Taksz, L. (2017). Scientific background and development of methodological guidelines of county-level and local climate change strategies (in Hungarian: Klímastratégiai módszertanok tudományos megalapozása és kidolgozása leendő térségi és helyi klímastratégiákhoz. (eds. Taksz, L.) Hungarian Geological and Geophysical Institute, Budapest

Camagni, R. (2017). Territorial Impact Assessment (TIA): a methodological proposal. In Capello, R. (Ed.), Seminal studies in regional and urban economics (pp. 399-410). Springer: Berlin.

Canadell, J. G., \& Raupach, M. R. (2008). Managing Forests for Climate Change Mitigation, American Association for the Advancement of Science. 320(5882), 1456-1457. DOI: 10.1126/science. 1155458

Carvalho, M. G. (2012). EU energy and climate change strategy. Energy 40, 19-22.

Central Statistical Office (2013). Economic Processes Regional Differences https://www.ksh.hu/docs/hun/xftp/idoszaki/regiok/debrecengazdfejl/debrecengazdfej113 .pdf Download: 2019. March

$\begin{array}{llll}\text { Central Statistical } & \text { Office } & \text { (2018). }\end{array}$ https://www.ksh.hu/docs/hun/xstadat/xstadat_eves/i_wdsd003b.html Download: 2019. March https://www.ksh.hu/docs/hun/xstadat/xstadat_eves/i_qpt012b.html Download: 2019 March

EEE OP (2015). Environmental and Energy Efficiency OP Hungary. (Környezeti és Energiahatékonysági Operatív Program), 2014-2020. https://www.palyazat.gov.hu/download.php?objectId=53467 Download: 2019. March

HMS (2019). National Inventory Report for 1985-2017. Compiled by the Hungarian Meteorological Service. https://unfccc.int/documents/194931 Dowload 2019. April

Hoffman, I. (2018). Hungarian Counties and Regional development - Changing Roles in a Transforming Environment. Deturope. 10(3), 162-179

IPCC (2018). Summary for Policymakers. In: Global Warming of $1.5^{\circ} \mathrm{C}$. An IPCC Special Report on the impacts of global warming of $1.5^{\circ} \mathrm{C}$ above pre-industrial levels and related global greenhouse gas emission pathways, in the context of strengthening the global response to the threat of climate change, sustainable development, and efforts to eradicate poverty. Masson-Delmotte, V., P. Zhai, H.-O. Pörtner, D. Roberts, J. Skea, P.R. Shukla, 
A. Pirani, W. Moufouma-Okia, C. Péan, R. Pidcock, S. Connors, J.B.R. Matthews, Y. Chen, X. Zhou, M.I. Gomis, E. Lonnoy, T. Maycock, M. Tignor, and T. Waterfield (eds.). World Meteorological Organization, Geneva, Switzerland, 32 pp.

Iyer, G., Calvin, K., Clarke, L., Edmonds, J., Hultman, N., Hartin, C., ...Pizer, W. (2018). Implications of sustainable development considerations for comparability across nationally determined contributions. Nature Climate Change Volume 8, pages 124-129

Laukkonen, J., Blanco, P. K., Lenhart, J., Keiner, M., Cavric, B., \& Kinuthia-Njenga, C. (2009). Combining climate change adaptation and mitigation measures at the local level. Habitat International 33 (2009) 287-292.

Lengyel, I \& Varga, A. (2018). A magyar gazdasági növekedés térbeli korlátai - helyzetkép és alapvető dilemmák. [Spatial constraints of Hungarian economic growth - state of play and basic dilemmas] Közgazdasági Szemle, LXV., May, 499-524.

Lennert, J., Csatári, B., Farkas, J. Z., \& Mezőszentgyörgyi, D. (2015). Locality-based and placebased development in theory and practice - an example of the Hungarian countryside. Deturope, 7(2), 14-27.

Lukovics, M. (2012). Regionális gazdaságfejlesztés: eltérő fejlettségü megyék versenyképességének összehasonlító elemzése. [Regional economic development: comparative analysis of the competitiveness of counties with different levels of development] A TDK világa. Szegedi Tudományegyetem Gazdaságtudományi Kar, Szeged, 67-89. o. http://acta.bibl.u-szeged.hu/32223/1/tdk_067-089.pdf Download: 2019 March

NCCS-2 (2018) Second National Climate Change Strategy 2018-2030, with an outlook for 2050. (23/2018. (X. 31.) OGY határozat a 2018-2030 közötti időszakra vonatkozó, 2050-ig tartó időszakra is kitekintést nyújtó második Nemzeti Éghajlatváltozási Stratégia) http://www.kormany.hu/download/f/6a/f0000/N\%C3\%89S_2_strat\%C3\%A9gia_2017_ 02_27.pdf Download: 2018. November.

NFSSD (2013). National Framework Strategy of Sustainable Development. Hungary, National Council for Sustainable Development, (ed Bartus, G.) ISBN 978-963-08-7737-4

OECD (2008). Competitive Cities and Climate Change. http://search.oecd.org/cfe/regionalpolicy/50594939.pdf Download: 2019. March

Pálvölgyi, T., \& Czira, T. (2018). Methodology for climate change strategies and experiences in preparation of them. (in Hungarian: A klímastratégiák módszertana és elkészítésük szakmai tapasztalatai). In: Sági, Z. and Pál, K. (eds.) Mérsékelt öv? Felelös cselekvési irányok a hatékony klímavédelemért. Budapest, Magyarország, Klímabarát Települések Szövetsége, (2018) pp. 101-123. , 23 p.

TOP (2014). Territorial and settlement development OP https://ec.europa.eu/regional_policy/en/atlas/programmes/2014-

2020/hungary/2014hu16m2op001 Download: 2019 March

Ürge-Vorsatz, D., \& Herrero, S. T. (2012). Building synergies between climate change mitigation and energy poverty alleviation. Energy Policy Volume 49, Pages 83-90

Wende, W., Bond, A., Bobylev, N., \& Stratmann, L. (2012). Climate change mitigation and adaptation in strategic environmental assessment. Environmental Impact Assessment Review 32, 88-93

Zhou, Y., Liu, Y., Wu, W., \& Li, Y. (2015). Effects of rural-urban development transformation on energy consumption and CO2 emissions: A regional analysis in China. Renewable and Sustainable Energy Reviews 52, 863-875

Zsibók, Z., \& Sebestyén, T. (2017). Regionális gazdasági előrejelző modell, a klímaváltozás figyelembevételével. [Regional Economic Forecasting Model with Respect to the Climate Change] Területi Statisztika, 57(2), 132-159 